University for Business and Technology in Kosovo

UBT Knowledge Center

UBT International Conference

2015 UBT International Conference

Nov 7th, 9:00 AM - 5:00 PM

\title{
Influence of the party system on the foreign policy
}

Aleksandra Jaskólska

University of Warsaw, a.jaskolska@uw.edu.pl

Follow this and additional works at: https://knowledgecenter.ubt-uni.net/conference

Part of the Political Science Commons

\section{Recommended Citation}

Jaskólska, Aleksandra, "Influence of the party system on the foreign policy" (2015). UBT International Conference. 7.

https://knowledgecenter.ubt-uni.net/conference/2015/all-events/7

This Event is brought to you for free and open access by the Publication and Journals at UBT Knowledge Center. It has been accepted for inclusion in UBT International Conference by an authorized administrator of UBT Knowledge Center. For more information, please contact knowledge.center@ubt-uni.net. 


\title{
Influence of the party system on the foreign policy
}

\author{
Aleks andra Jaskólska \\ Centre for Contemporary India Research and Studies \\ Institute of International Relations, Żurawia 4, Warsaw \\ University of Warsaw, Poland \\ a.jaskolska@uw.edu.pl
}

\begin{abstract}
In my paper I will analyze influence of the party system on the foreign policy, case study: India. Indian party system evaluated from dominant party system (sometimes this period of time is called one party system, but it not correct) to multiparty system. India got independence on 15th August 1947, three years later become a republic. India adopted democracy and multiparty system (1951/52, first election for central government, after independence). Even though that multisystem party was introduce, Indian National Congress (INC) ruled India from 1947 till 1977. INC came to power again in 1980 and ruled till 1989 and then came to power in 1991. From the end of 90s coalition period in Indian politics has started. Till 2014, when Bharatiy a Janata Party (BJP) came in to power, no single party could win election. Research question: how big is the influence of party sy stem on the foreign policy of India?
\end{abstract}

Keywords: India, party system, Indian National Congress, BJP, Foreign Policy

First of all it is important to define party system and to classify party systems. "Parties make for a system, then only when they are parts (in the plural) and a party system is precisely the system of interactions resulting from inter-party competition. That is, the system in question bears on the relatedness of parties to each other, on how each party is a function of the other parties and reacts, competitively or otherwise, to the other parties" (Giovanni Sartori 1976). The initial classification of party systems relied on quantitative measures of size and relative size. First, Duverger's (1954) distinction between two party and multiparty systems. Blondel (1968) proposed four categories (based more on vote shares than seat shares): two- party systems (two-party share of 90 percent or more), three-party or two-and-a half-party sy stems (two-party vote share between 75 and 80 percent), multiparty sy stems with a dominant party (dominant party obtaining about 40 percent of the votes and about twice as much as the second party), and multiparty systems without a dominant party. Classification of party systems according to Sartori (1976) is based on the number of parties vying to gain power. In the 1990s, Ware (1996) provided a schema which returned to using quantitative measures. Indian party system went through enormous change from dominant party system to multiparty system. In many countries which used to be colonies, the parties which have "won independence", introduce a law that prevented the functioning of other parties. In India, such a situation didn't occur. Why in India multi-party system was established? Indian researcher, Rajni Kothari (1970) explains the specifics of India was caused by religious, ethnic and social diversity. India become independence state on 15 August 1947. Three years later on 26 January, Indian constitution came to power, and India became a socialist, secular, democratic republic (Wolpert 2000). The evolution of the party system since India's independence can be divided into four stages: 1947-1967 - domination of Indian National Congress (Congress, INC), 1967-1989 consolidation of the opposition and the emergence of a multi-party system, from 1989 to 1998 - a time of change, 1998-nowadays formation of the coalition system. Congress was a dominant party due to the lack of a lot of similar potential in any other Indian party. The only party that could endanger Congress was Muslim League, but after 1947 it disappeared from the political scene. After death of longtime leader of Congress, Jawaharlal Nehru (1964), INC began to divide. When in 1966 Nehru's daughter, Indira Gandhi became the new leader of Congress, unrest within the party began to grow. At that time, also, anti-Congress parties grew in strength (Tully 2007). The change in the party sy stem emphasized the end of the dominant party system in India. The emergence of Janata Party, which 
consisted of the party which were in opposition to Congress (Socialist Party, Bharatiya Lok Dal, Bharatiy a Jan Sang, Congress (O)) won elections in 1977 and changed the Indian political scene. The dominant party sy stem could be replaced by two-party system. However, it soon turned out that it was impossible. Janata Party was too weak. After two years, the coalition fell apart and Congress was back to power. In 1980 Bharatiya Janata Party was created, which later grow into the biggest rival of the Congress (Das 2007). India in 1989 entered a phase of coalition governments. Yogendra Yadav (2008) called the situation a "post Congress polity", it means that the political scene is not only the Congress and the party that want to compete with it, but also BJP and other parties (regional parties). Year 1989 is the beginning of the end of the domination of Congress, which was unable in later years to rebuild its influence on the Indian political scene. Why Congress began to lose support in the late 80s? Muslims didn't feel as much danger as the 1947 and decided to move away from the Congress and seek the support from other parties. Business middle class, merchants, small businesses, were against state control over the economy, and the upper-middle class, was against the Congress because they were discouraged by its bureaucracy and socialist approach to economic development (Tharoor 2007). Large part of the middle class turned to the Bharatiya Janata Party (BJP). The political scene was very unstable, V.P. Singh government survived only 11 months (December 1989 to November 1990). Then the head of government became Chandra Shekhar (November 1990 to June 1991). At that time there was a war in the Gulf, none of these governments were able to react to it. In June 1991, Congress came to power (minority government), Prime Minister Narasimha Rao maintained his position for a full term, until 1996. Many of the changes were introduced to the foreign policy of India during this period, including establishing diplomatic relations with Israel (1993); boarder agreement with China (1993), significant improvement in relations with the US and beginning of implementation of the 'Look East' policy. Once again after Rao government situation become unstable (Kachru 2007). Atal Behari Vajpayee, leader of BJP, was the leader of coalition which gained power only for two weeks (16 May - 1 June 1996). The next government, headed by Deve Gowda, remained in power from June 1996 to April 1997. IK Gujral, who was foreign minister in Gowda's government, became next prime minister (April 1997 to March 1998). Finally BJP came to power as a leader of the coalition, National Democratic Alliance (1998-2004). INC came to power again in 2004 but was not able to rule the country alone, INC was forced to create a coalition. United Progressive Alliance (UPA) was ruling India for two full terms from 2004 till 2014. For the first time the Congress was forced to created such a big coalition, this has begun a new era for the party (Dixit 2005).India party system, went through big transformation from dominant party to a multiparty system. Number of political parties since the first elections in 1952 has increased several dozen times. After 2004, many researchers, including D. L. Sheth (2004) acknowledged that Indian party system is based on a twoparty coalition system. In last parliamentary elections which were held in April and May 2014, BJP won enough number of seats to rule the country alone (first time since 1984) Congress was badly defeated. So is it the end of two-party coalition system? It is definitely too early to say. I believe that to answer this question, it is necessary to wait till next elections in 2019.

After analyzing changes in the party system of India, it is important to examine how foreign policy of India was changing since independence. Congress has dominated for many years the state's foreign policy. According to Harsh Pant (2009), this was due to lack of interest and apathy among elites, whom were too lazy to strive for change. Finally, changes in the international arena, have forced India to change its foreign policy. End of 90 s it is definite as the end of "Congress system". There was a new strong player on the Indian political scene, BJP. BJP create coalition and won the elections in 1998 and then in 1999 and 2014. According to Uday Bhaskar (2007), Indian foreign policy can be divide into four phases: 1947-1962, 1962-1991, 1991-1998 and from 1998 till now. First phase from independence till war with China was influence by ideology of first prime minister of India, Jawaharlal Nehru (leader of INC). Nehru believed in the ideology of non-alignment, which became ideological base for Non-Alignment Movement (NAM). Most important principles: mutual respect for each other's territorial integrity and sovereignty; mutual non-aggression; mutual non-interference in domestic affairs; equality and mutual benefit; peaceful co-existence. Nehru believed that relations between India and China will be always based on friendship and mutual respect. He didn't suspect that China will decide to attack India. But it happened in 1962. India was not ready for this war and was badly defeated. It was the end of idealistic approach. It was the beginning of nehruvian militarism. Second phase from war with China till the end of cold war. Nehru died in 1964, Lal Bahadur Shastri from INC become prime minister. He continued the idea of foreign policy introduced by Nehru. Two years later Nehru's daughter Indira Gandhi become prime minister. After the war with China in 1962 
and the war with Pakistan in 1971, Indira Gandhi decided to increase military spending. Indira Doctrine was based on: close cooperation with the USSR (August 9, 1971 signed the Treaty of Peace, Friendship and Cooperation), building a strong position of India in South Asia, weakening position of Pakistan (war in 1971, which led to the creation of Bangladesh). In addition, Indira decided to carry out nuclear weapons tests in 1974 (the program Smiling Buddha). Indira was killed on 1984, she was succeeded by her son, Rajiv Gandhi. He worked to improve relations with China, the US and Pakistan. We also support all the activities connected with the development of relations with neighboring countries. He supported nuclear disarmament and plan to establish in the Indian Ocean, "a zone of peace". Rajiv Gandhi last in elections in 1989. Due to unstable political situation, there were not significant changes in the foreign policy till 1991. End of cold was brought huge change to foreign policy of India. INC was in power (1991-1996. After the end of the Cold War, main goal was to improve relations with the United States and new normalization of relations with Pakistan and China. India in the 90s had to change the policy approach in the South Asia region. Step by step, India departed from unilateralism in favor of multilateralism. Allowed for other countries to resolve political crises in the region (eg. In Sri Lanka and Nepal). Moreover, they began to promote the development of South Asia Association of Regional Cooperation (SAARC). Also decided to accept observers to SAARC (US, China, Japan). The new policy in the region was based on the development of economic cooperation, cooperation in the energy sector and not on the earlier assumption of the unity of developing countries. After many years rejected the idea of regionalism, India actively working in international organizations such as ASEAN, East Asia Summit and African Union. Next phase of foreign policy of India started after successful nuclear test in 1998 (decision it has taken place has been taken by the Bharatiya Janata Party and prime minister Atal Bihari Vajpayee). India's policy has become yet another dimension. BJP manage to improve relations with the US and with Pakistan (despite the nuclear test). INC as a leader of NDA (2004-2014) was not always able to implement foreign policy by itself. INC was not a dominant party any more, it was a part of coalition. Even though that BJP in election in 2014 won enough number of seats to rule the country alone (first time since 1984), it doesn't mean that it can implement any foreign policy it want to. It is important to underline that Indian sy stem party is multiparty sy stem and there is no more space for one dominant party. The change in India's foreign policy was influenced not only by party system and politicians personalities but also by international pressure and situation in the international arena. Each of these factors plays a different role. In the case of India a very important internal determinant that shapes foreign policy is the personality of prime minister. To classify the personalities of Indian prime ministers, it is very useful to use a tool created by Margaret Hermann, Profiler Plus (1976). The program calculates and organizes the words used by politicians during interviews, press conferences and interviews. M. Hermann classify leadership styles and to present the analy sis, based on which one can predict how a leader reacts to the situation within the country and internationally. But in this paper I would like to focus on answering the question: how changes in the foreign policy of India are related to changes in Indian party system. So I will not analyze work of M. Hermann in details. To answer above question it is crucial to analyze formal institutions which have influence on the foreign policy of India: prime minister, parliament and political parties, etc (Kohli 1991). In comparison, for the example with the US presidential system, the parliament of India plays a less important role in shaping foreign policy. The Indian parliament is discussing only on issues related to the possibility of war and crisis, regional or international level. The government doesn't need to ask parliament for ap proval of the agreements and treaties. Members of parliament can request the prime minister or the foreign minister to give statement regarding any international issue having influence on the foreign policy. Opposition parties can bring a no-confidence motion against the Prime Minister on any serious issues related to the country's foreign policy. Prime Minister Jawaharlal Nehru faced first noconfidence motion after war with China in 1962. In 2005, the Left Parties withdrew support for Manmohan Singh government on the issue of India-US Civil Nuclear Deal (Ollapally, Rajagopalan 2011). Same situation happened in 2013 when DMK (regional party from Tamil Nadu) has pulled out of the Congress-led UPA coalition in protest against the government's position on a United Nations resolution on the bloody end to Sri Lanka's civil war with the separatist Tamil Tigers. The Parliament can have influence on the foreign policy of the country also through various Parliamentary Committees. The Estimate Committee and the Public Accounts Committee exercise influence foreign policy through its control of finances to the Ministry of External Affairs. In 1960-1961, the Estimate Committee had recommended reorganization of the Foreign Office and the missions abroad. The Consultative Committee of Parliament on External Affairs holds regular discussions on various 
aspects of the country's foreign policy, even though its conclusions or recommendations are not binding on the government. M.C. Chagla (2000), India's Minister of External Affairs in Indira Gandhi's cabinet, observed, "The Consultative Committee is more of an agency for get ting policies accepted and muting criticism than for influencing foreign policy." Overall, parliament provides free hand to the executive to formulate and implement the foreign policy. Government shows sensitivity to the opinion generated through parliamentary debates. Vajpeyee's government refusal to join the US-led war in Iraq in year 2003, was a result of parliament's intervention in guiding the government to decide upon international issues. The Cabinet, in parliamentary sy stem should play an important role in creating foreign policy. However, in India, this used to be only theory, in practice prime minister Jawaharlal Nehru, Indira Gandhi, Rajiv Gandhi and Narasimha Rao, were making decisions mostly alone. The situation has not changed much when coalition system started. Vajpeyee enjoyed great autonomy of decision in the government Moraraji Desai (in 1977-1979) in which he was foreign minister. Similarly, Indra Kumar Gujaral could decide on the shape of India's foreign policy as foreign minister in VP Singh's government (1989-1990) and in the H.D. Deve Gowda's government (19961997). I.K. Gujaral replaced Deve Gowda as prime minister for a very short period of time during the reign of United Front. Soon, he returned to serve as foreign minister in the government of Narasimha Rao. He no longer had as much autonomy as before (especially when it came to policy toward the United States, China and Pakistan). In conclusion, Ministry of External Affairs plays an important role in formulating and implementing foreign policy of India. The Ministry provides infrastructure, necessary information, presents recommendations and analysis which are necessary for decisionmaking. Until 1964 there was also a position of Secretary-General, who was an advisor to the minister of foreign affairs. This function was very useful to Nehru, who was not only the prime minister but also the foreign minister. Secretary-General was necessary to coordinate implementation of foreign policy. After the death of Nehru, Lal Bahadur Shastri, decided to cancel this position. Ministry of External Affairs, has also special units, which have an impact on foreign policy: Historical Division, Policy Planning and Review Division, Policy Advisory Committee (Mehta 2009). When Rajiv Gandhi became prime minister, Indian Foreign Service members began to play a greater role in formulating and implementing foreign policy. Prime Minister Atal Bihari was Vajpeyee, created the post of National Security Advisor, who worked closely with the Ministry of Foreign Affairs, Ministry of Defense and Internal Affairs (Dugis 2009-08). Formal institutions which have influence on the foreign policy of India are still changing. To sum up, Indian party system went through enormous change from dominant party system to multiparty system. This process had clearly impact on the foreign policy of India. The stages of evolution of the party system since India's independence can be compared to the phases of the foreign policy of India. Formal institutions which have influence on the foreign policy of India had changed since independence. Decision making process in much more complex now that 50-60 years ago. Changes in Indian party system are very dynamic.India will be facing new challenges in coming years.

\section{References}

1. Bhaskar, U.C.: Indian Foreign Policy Orientation in the Twenty-First Century: Continuity and Change. New Delhi (2007)

2. Blondel , J.: 'Party Systems and Patterns of 'Government in Western Democracies', Canadian journal of Political Science, $1 / 2$ (1968)

3. Calvert, P.: The Foreign Policy of New States. Sussex: Wheatsheaf (1986)

4. Chagla M.C.: Roses In December, an autobiography, Bharatiy a Vidya Bhavan, (2000)

5. Clapham, Ch.: ed. Foreign Policy Making in Developing States, A Comparative Approac. Westmead, England: Saxon House (1977)

6. Das G.:India unbound, New Delhi, Penguin Books (2007)

7. De Rivera, Joseph H., The Psy chological Dimension of Foreign Policy. Columbus, Ohio: Charles E. Merrill (1968)

8. Dixit J.N.: Indian foreign service, New Delhi, Konark Publisheers (2005)

9. Dugis V.: Domestic Political Structure and Public Influence on Foreign Policy, A Basic Model , Jurnal Global dan Strategis, vol.3, nr 2, (2009-08),

10. Duverger, M.: (1954): Political Parties: Their Organization and Activity in the Modern State. Wiley, New York (1954) 
11. Frankel, Joseph, The Making of Foreign Policy. London: Oxford University Press (1963)

12. Hermann, M.: Hermann, Margaret G. Circumstances under which leader personality will affect foreign policy: Some propositions. In Search of Global Patterns. New York: Free Press (1976)

13. Kachru U.: Extreme Turbulence, India at the Crossroads, New Delhi, HarperCollins (2007)

14. Knutsen, T.L.: A History of International Relations Theory. Manchester \& New York: Manchester University Press (1992)

15. Kohli, A.: Democracy and Discontent: India's Growing Crisis of Governability, New York (1991)

16. Kothari, R.: Politics in India. Orient Blackswan, New Delhi (1970)

17. Mansbach, R.W.: The Global Puzzle, Issues and Actors in World Politics. Boston \& New York: Houghton Mifflin (2000)

18. Mehta P.B.: Still Under Nehru's Shadow? The Absence of Foreign Policy Frameworks in India, India Review, 8:3 (2009)

19. Modelski, G.: A Theory of Foreign Policy. New York: Praeger (1962)

20. Morgenthau, H. J.: Politics Among Nations: The Struggle for Power and Peace. 4th edition, New York: Alfred A. Knopf (1978).

21. Ollapally D., Rajagopalan R.: The Pragmatic Challenge to Indian Foreign Policy, The Washington Quarterly, (Spring 2011)

22. Pant, H. V. Indian Foreign Policy Challenges: Substantive Uncertainties and Institutional Infirmities, Asian Affairs, Vol. 40:1, (2009)

23. Sartori G.: Parties and Party Sy stems. Cambridge: Cambridge University Press (1976)

24. Sheth, D.L.:The Crisis of Political Authority. In: Vora R. \& Palshikar S. (eds.): Indian Democracy: Meanings and Practices, Sage, Delhi, (2004)

25. Tharoor S.: India, from midnicht to the Millenium and Beyond, New Delhi, Pengiun Books (2007)

26. Tully M.: India's unending journey, Kent, Rider (2007)

27. Waltz, K. N.: Foreign Policy and Democratic Politics, The American and British Experience. Boston \& Toronto: Brown, Little (1967)

28. Ware, A.: Political Parties and Party Systems. New York: Oxford University (1996)

29. Wilkenfeld, J.: Foreign Policy Behaviour, The Interstate Behaviour Analysis Model. London: Sage (1980)

30. Wolpert S.: A New history of India, Oxford University Press (2000)

31. Yadav Y., Shastri S. and Suri K.C.: State of Democracy in South Asia OUP, New Delhi (2008) 